Удк [338.36:652.8] (449)

\author{
Кулаковська Т.A. \\ кандидат економічних наук, доцент \\ E-mail: tatyana_kula@mail.ru \\ Колесник Е.В. \\ магістрант \\ кафедра економіки промисловості \\ Одеська національна академія харчових технологій \\ вул. Канатна, 112, м. Одеса, Україна, 65039 \\ E-mail: edward-kol@mail.ru
}

\title{
ОГЛЯД РИНКУ КОМБІКОРМОВОЇ ПРОМИСЛОВОСТІ УКРАЇНИ
}

В статті відображено стан комбікормової промисловості та конкурентного оточення, надана характеристика наявних проблем промисловості, динаміка виробництва та споживання комбікормів. Також обгрунтовані шляхи подальшого ефективного розвитку галузі.

Ключові слова: комбікормова промисловість, структура ринку, виробництво, експорт, імпорт, комбікормова продукція.

Постановка проблеми та її зв'язок з важливими науковими i практичними завданнями. Комбікормова промисловість Україні потребує значної уваги, так як ця галузь є одним із основних факторів розвитку птахівництва та тваринництва. За часи незалежності України загальний рівень виробництва комбікормів значно знизився, були зруйновані зв'язки 3 колишніми республіками, що призвело до негативних наслідків в експортній та імпортній можливостях комбікормової промисловості. В свою чергу низький рівень прибутковості галузі, обмеженість обігових коштів і доступу до кредитних ресурсів зумовили істотне скорочення поголів'я тварин та птиці у сільськогосподарських підприємствах [9]. Тому для більш якісного аналізу стану та окреслення перспектив розвитку комбікормової промисловості України необхідно досліджувати тенденції, що склалися в сучасних умовах.

Аналіз останніх публікацій 3 проблеми. Маркетингу агропромислової продукції присвячено достатньо вітчизняних та зарубіжних досліджень, у тому числі таких авторів, як В.І. Благодатний, А.В. Войчак, В.М. Геець, Л.В. Дейнеко, І.В. Роздольська, Н.П. Шалигіна та інші. Однак недостатньо розглянуті питання огляду ринку комбікормової промисловості України, що і зумовлює актуальність даної статті.

Формулювання цілей дослідження. Метою даної статті є аналіз стану комбікормової промисловості України, дослідження динаміки розвитку та окреслення основних тенденцій розвитку.

Дослідження розвитку комбікормової промисловості буде проводитися за такими основними напрямками: становлення комбікормової промисловості України, вплив динаміки поголів'я птиці та скоту на виробництво комбікормів, загальна динаміка виробництва комбікормів, структура ринку за призначенням комбікормів, аналіз частки основних вітчизняних виробників комбікормової продукції.
Виклад основних результатів та їх обгрунтування. Розвиток вітчизняної комбікормової промисловості за часів Радянського Союзу відбувався в напрямі задоволення потреб великих тваринницьких комплексів, на яких утримувалося багатотисячне поголів'я.

В той період в Україні було збудовано близько 90 комбікормових заводів-гігантів, які випускали щорічно майже 16 млн. тонн комбікормів при максимальній потужності 21,8 млн. тонн. Значна роль у забезпеченні тваринництва та птахівництва комбікормами відводилася міжгосподарським комбікормовим заводам, на які припадало $46 \%$ загальної потужності підприємств комбікормової промисловості.

Обсягами продукції, що вироблялася в ті часи комбікормовою промисловістю, практично повністю забезпечувалися потреби тваринництва, тобто майже 31-33 млн. голів умовного поголів'я великої рогатої худоби, що утримувалося в сільськогосподарських підприємствах [9].

Після розпаду СРСР виробництво комбікормів в Україні значно знизилося, були порушені налагоджені в минулому зв'язки з колишніми республіками, що позначилося на експорті-імпорті комбікормів. Занепад вітчизняних сільгосппідприємств призвів до скорочення поголів'я великої рогатої худоби, свиней, птиці, i, як наслідок, комбікорм виявився незатребуваним. В результаті обсяги виробництва кормів значно зменшилися - з 16,5 млн. тонн у 1990 році до 1,1 млн. тонн в 2000 р. [10].

На даний час головною особливістю українського ринку комбікормів є значне перевищення виробничих потужностей над фактичним рівнем виробництва. Потенційні потужності 3 випуску комбікормів, за різними оцінками, становлять 12-18 млн. тонн на рік. Це промислові підприємства, підприємства малого бізнесу, кормоцехи. На думку операторів ринку, комбікормові заводи використовують свої 
потужності на $30 \%$. Винятком є підприємства, що входять до складу великих агрохолдингів і мають власні тваринницькі комплекси, які забезпечують їм стабільний збут продукції. Ці підприємства можуть завантажити свої виробничі потужності повністю і навіть відчувати в них нестачу [3].

Однак аналіз діяльності комбікормової промисловості за останні роки вказує на те, що виробництво кормів з кожним роком збільшується, що можна побачити на рис. 1 [4].

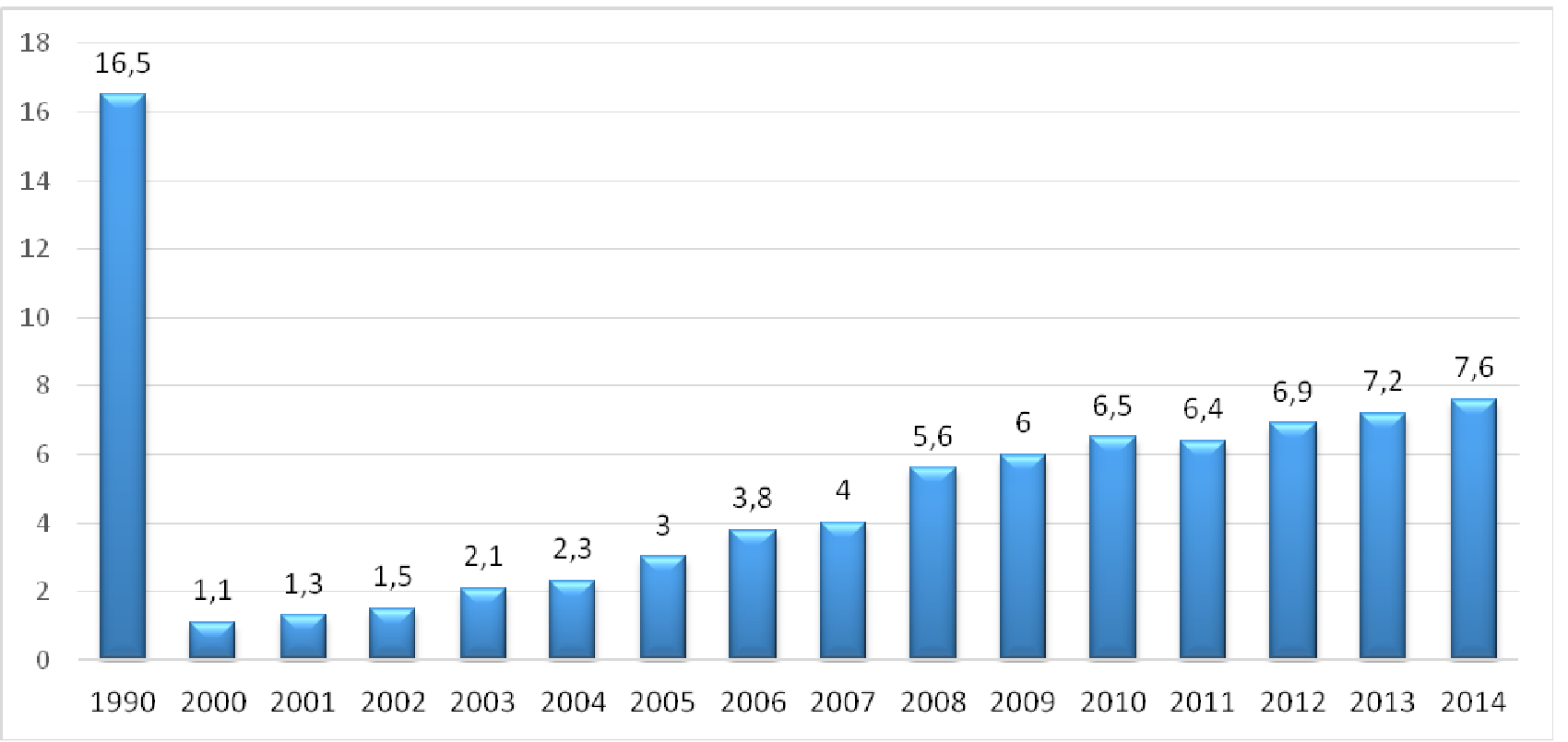

Рис. 1. Виробництво комбікормів в Україні 1990-2014 роки, млн. тонн

Джерело: Згідно даних: www.apn-ua.com, www.agronews.ua, «Інтерфакс-Україна», «Союз кормовиробників України»

Загалом за період з 2008 по 2013 роки обсяг виробництва комбікормів зріс майже на $40 \%$ у натуральному вираженні та в 4 рази у грошовому. Треба сказати, що на протязі досліджуваного періоду нарощування обсягів виробництва не було стабільним. Нестабільність зростання обсягів виробництва пояснюється залежністю виробництва від рівня споживання 3 причини низького рівня експорту. Значні обсяги продукції виробляють малі підприємства, оснащені примітивним обладнанням. Це свідчить про те, що вітчизняна комбікормова промисловість орієнтується лише на внутрішнього споживача, обмежуючи цим власний розвиток як перспективної галузі [5].

Зростання обсягів виробництва, перш за все, пов'язано з приростом поголів' я свиней та птиці (рис. 2), що, в свою чергу, $\epsilon$ наслідком приходу в тваринницьку галузь України крупних інвесторів, які почали займатися відродженням великотоварного виробництва м'яса в живій вазі.

Також структуру ринку за призначенням комбікормів можна розглянути на рисунку 3.3 рис. 3 видно, що найбільша потреба у комбікормах є саме у сфері птахівництва, потім йде свинарство та скотарство. Саме свиноводи та птахівники є головною рушійною силою вітчизняного кормовиробництва.

За даними Держстату, у 2013 році поголів'я птиці зросло на 6,7\% - до 246,9 млн. голів, а свиней на $4,6 \%$, до 8,2 млн. голів. Також за минулий рік на 5,1\% зросла кількість овець та кіз, на 3,5\% - кількість великої рогатої худоби [6].

Особливістю українського кормовиробництва $\epsilon$ вертикальна інтеграція, при якій одне підприємство холдингу вирощує зернові, друге виробляє 3 них комбікорми, а третє - згодовує худобі чи птиці, тоді як в Свропі виробники комбікормів незалежні підприємства. Відтак основне виробництво у нас «прив'язане» до власного споживання, а основні потужності з виробництва комбікормів зосереджені у регіонах з найбільшим поголів'ям [3].

Особливістю є також те, що $40 \%$ ринку знаходиться в тіні. А 8 найбільших підприємств виробляють 53\% всіх кормів [1]. 
Поголів'я скоту (ліва шкала) та птиці (права шкала), тис. голів.

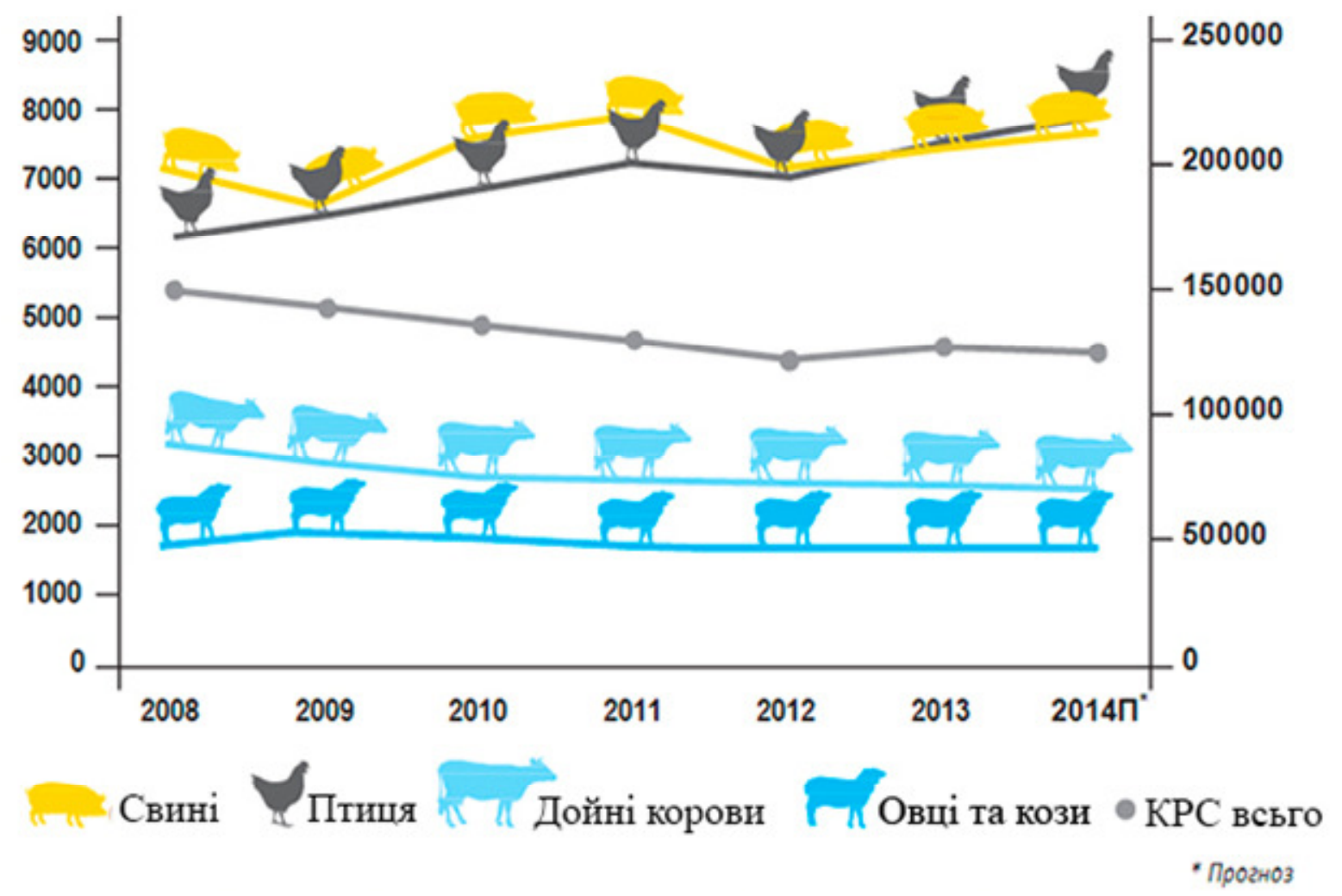

Рис. 2. Динаміка поголів'я птиці та скоту за 2008-2014 роки, тис. голів Джерело: Державна служба статистики України, Bussines Monitor International [2]

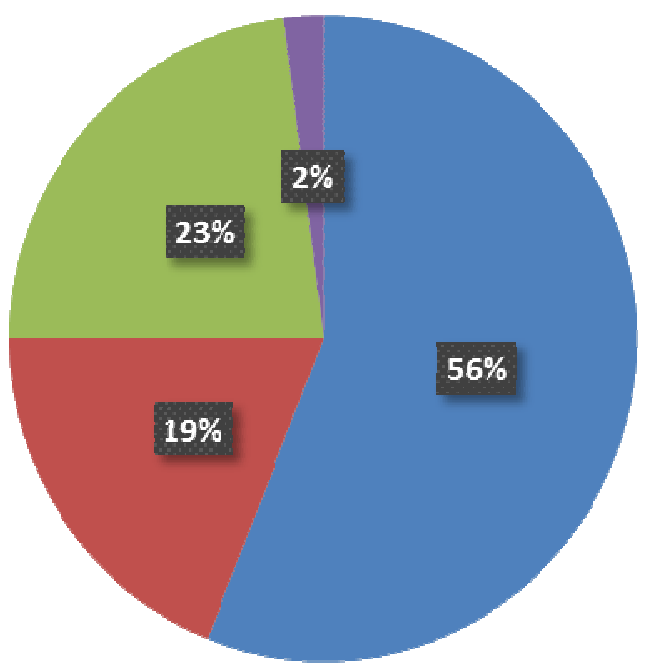

- Комбікорма для птиці

- Комбікорма для ВРЧ

Кобікорма для свиней

- Інші комбікорма

Рис. 3. Структура ринку за призначенням комбікормів у відсотковому відношенні

Що стосується структури українського ринку виробників комбікормів, то вона така: на ринку України працює близько 120 виробників комбікормів, виробничі потужності яких дозволяють випускати 12-
15 млн. тонн на рік, проте вони завантажені лише на 30-35\%. Провідними виробниками комбікормів $\epsilon$ наступні підприємства, які структуровані за критері$\epsilon м$ - обсяг виробництва в тис. тонн (рис. 4): 


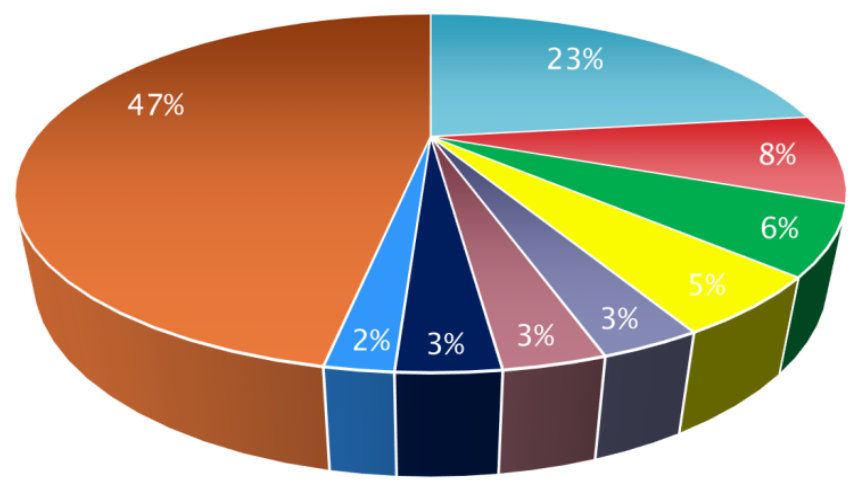

$$
\begin{aligned}
& \text { - 1.««Миронівський хлібопродукт»» } \\
& \text { - 3.«Комплекс Агромарс» } \\
& \text { - 5.«Агро-Овен» } \\
& \text { - 7.Птахокомбінат «Дніпровський» } \\
& \text { - Інші компанії }
\end{aligned}
$$

$$
\begin{aligned}
& \text { - } 2 . U k r L a n d F a r m i n g \\
& \text { - 4.«Єдність» } \\
& \text { - 6.«АПК-Інвест» } \\
& \text { - 8.«Фідлайн» }
\end{aligned}
$$

\section{Рис. 4. Провідні виробники комбікормової продукції в Україні}

При цьому географічно найбільші потужності 3 виробництва кормів знаходяться в областях, де зосереджено основне поголів'я птиці, свиней, ВРХ, - у Черкаській (16 \%), Київської (14 \%), Дніпропетровській $(10 \%)$, Донецької (9\%), Вінницькій ( 7 \%), Полтавській (7 \%) та інших (37\%).

В 2013 році Україна експортувала 15 тис. тонн комбікормів і кормових добавок, преміксів на 9,4 млн дол., в основному в Грузію (57,2\%) і Молдову (26,3\%).

Невеликі об'єми експорту пов'язані з тим, що комбікорми - це нетранспортабельна продукція (крім гранульованих) і перевозяться на відстань не більше як 100 кілометрів.

При цьому Україна імпортувала 128 тис. тонн кормових добавок, преміксів і амінокислот на 248 млн дол.

В імпорті переважають премікси з Європи та лізини з Китаю, а в експорті - повнораціонні корми та корми на основі зерносуміші [7].

Висновки i перспективи подальших досліджень. На протязі перших років становлення нашої держави агропромисловий комплекс країни був охоплений кризовими явищами. Найбільшої руйнації зазнали тваринницька галузь та комбікормова промисловість, що її забезпечує.

На даний час, в нашій країні виробляються комбікорми низької якості: зернові складові становлять у середньому понад 70\%, що значно вище за рекомендації стандартів ЄС. Через відсутність необхідних компонентів комбікорми не збалансовані за основними поживними і біологічно-активними речовинами.

Також недостатній технологічний рівень переробки, лише 20\% продукції виготовляється у вигляді гранул та комбікормової крупки. Через низьку платоспроможність вітчизняних споживачів реалізується лише $80 \%$ вироблених комбікормів, майже відсутній їх експорт

Однак в останні роки в Україні з'явилась тенденція збільшення промислового виробництва тваринницькими підприємствами, що $є$ основним чинником збільшення споживання кормів та зростання вітчизняного комбікормового ринку.

Виробництво комбікормів на сучасному етапі зосереджено на підприємствах, що входять до складу великих агрохолдингів і мають власні тваринницькі комплекси, які забезпечують їм стабільний збут.

Технічна оснащеність лише $40 \%$ комбікормових заводів відповідає сучасним вимогам науково-технічного прогресу; до $30 \%$ потребують часткової реконструкції, а $30 \%$ - докорінної реконструкції та дооснащення. Стан, що склався, зумовлений незадовільним фінансовим положенням як галузі в цілому, так зокрема комбікормових підприємств та машинобудівних заводів, відсутністю економічно обгрунтованих механізмів його покращення. Тому капітальні вкладення, матеріальні і трудові ресурси у період стабілізації виробництва вигідно сконцентрувати у першу чергу на реконструкції діючих комбікормових підприємств, впровадженні на них провідних технологій, конкурентоспроможного устаткування.

\section{Література}

1. Газета "Урядовий кур'єр" [Електронний ресурс]. - Режим доступу : http://ukurier.gov.ua/uk/articles/ ukrayina-jde-na-rekord/.

2. Державний комітет статистики України [Електронний ресурс]. - Режим доступу : http://www.ukrstat.gov.ua. 
3. Журнал «АГРОПРОФІ» [Електронний ресурс]. - Режим доступу : http://www.agroprofi.com.ua/ statti/1057-efektivni-kormi--statistichni-diva.

4. Інформаційне агентство «AgroNews» [Електронний ресурс] - Режим доступу: http://agronews.ua/node/48203.

5. Інформацйна компанія "ПроАгро" [Електронний ресурс] - Режим доступу : www.proagro.com.ua

6. Просвітів Г. І. Маркетингові дослідження. Завдання й рішення. -М. : Альфа-Пресс, 2008

7. Топ 8 виробників комбікормів в Україні [Електронний ресурс]. - Режим доступу : http://latifundist.com/novosti/22186-top-8-proizvoditelej-kombikormov-v-ukraine.

8. «Український клуб аграрного бізнесу» [Електронний ресурс]. - Режим доступу : http://ucab.ua/files/Survey/Doslidjenna/Manual_UCAB.pdf.

9. Ярославський О. Огляд ситуації на ринку комбікормів в Україні. Проект "Аграрна політика для людського розвитку" [Електронний ресурс] - Режим доступу: http://www.undp.org.ua/agro/pub/ua/P2003_01_04 1_03.pdf.

10. FIVEX ANALYTICS GROUP [Електронний ресурс] - Режим доступу : www.fivex.com.ua.

Стаття надійшла 24.03.15

\author{
Кулаковская Т.A. \\ кандидат экономических наук, доцент \\ E-mail: tatyana_kula@mail.ru \\ Колесник э.В. \\ магистрант \\ кафедра экономики промышленности \\ Одесская национальная академия пищевых технологий \\ ул. Канатная, 112, г. Одесса, Украина, 65039 \\ E-mail: edward-kol@mail.ru
}

\title{
ОБЗОР РЫНКА КОМБИКОРМОВОЙ ПРОМЫШЛЕННОСТИ УКРАИНЫ
}

В статье отражено состояние комбикормовой промышленности и конкурентного окружения, дана характеристика существующих проблем промышленности, динамика производства и потребления комбикормов. Также обоснованы пути дальнейшего эффективного развития отрасли.

Отмечено, что комбикормовая промышленность как важная составляющая агропромышленного комплекса представляет собой один из основных факторов развития птицеводства и животноводства, влияет на продовольственную безопасность страны.

Однако сегодня комбикормовая промышленность Украины находится в трудном положении, что является актуальной проблемой. За годы независимости Украины производство комбикормов значительно снизилось, были разрушены налаженные связи с бывшими республиками, что негативно повлияло на экспорт и импорт комбикормов. Поэтому для проведения качественного обзора рынка комбикормовой промышленности Украины необходимо исследовать сформировавшиеся тенденции.

В современных условиях кормопроизводителям необходимо находить любые формы интеграции с животноводческими комплексами. Это объясняется тем, что массовая доля потребляемых в стране комбикормов приходится на сельскохозяйственные комплексы. Кормление комбикормами для них экономически выгодно. В отличие от хозяйств населения, в которых основой рациона животных являются подножные корма, а комбикорм - наоборот, часто используется в качестве подкормки.

Говоря о перспективах отечественного кормового производства, стоит заметить, что во многом отрасль зависит от государственной поддержки: эффективного дотирования, низких ставок кредитования и страхования рисков в животноводстве.

Ключевые слова: комбикормовая промышленность, структура рынка, производство, экспорт, импорт, комбикормовая продукция. 


\author{
Kulakovska T.A \\ Ph.D. in Economics, Associate Professor \\ E-mail: tatyana_kula@mail.ru \\ Kolesnik E.V. \\ Undergraduate \\ Department of Industrial Economics \\ Odessa National Academy of Food Technologies \\ Kanatna str., 112, Odessa, Ukraine, 65039 \\ E-mail: edward-kol@mail.ru
}

\title{
MARKET OVERVIEW FEED INDUSTRY IN UKRAINE
}

The article shows the status of the animal feed industry and the competitive environment, given ha tics of the problems the industry, the dynamics of production and consumption of feed.

It is noted, that the combined feed industry as an important component of agriculture, represents one of the main factors of poultry and livestock, affecting food security.

However, the current state of the feed industry of Ukraine is in a difficult position, which is a very urgent problem today.

Since independence, Ukraine has declined milling were destroyed good relations with the former republics that had a negative impact on exports and imports of animal feed. Therefore, for a quality review of the market feed industry Ukraine, should be investigated outlined in our time trends.

In modern terms feed production need to find any form of integration of livestock facilities. This is because the mass fraction of animal feed consumed in the country are agricultural complexes. Feeding fodder for them economically viable. Unlike households, which is the basis of the diet of animals grazing and feed on the contrary, often used as a dressing.

Speaking about the prospects of the domestic production of feed, it is worth noting that the industry is largely dependent on government support, effectively subsidizing, low rate financing and insurance risks in animal husbandry.

Keywords: feed mill industry, market structure, production, export, import, feed products.

\section{References}

1. Hazeta "Uriadovyi kurier" [Elektronnyi resurs]. Rezhym dostupu: http://ukurier.gov.ua/uk/articles/ ukrayinajde-na-rekord/.

2. Derzhavnyi komitet statystyky Ukrainy [Elektronnyi resurs]. Rezhym dostupu: http://www.ukrstat.gov.ua.

3. Zhurnal «AHROPROFI» [Elektronnyi resurs]. Rezhym dostupu: http://www.agroprofi. com.ua/statti/1057efektivni-kormi-statistichni-diva/.

4. Informatsiine ahentstvo «AgroNews» [Elektronnyi resurs]. Rezhym dostupu: http://agronews.ua/node/48203

5. Informatsina kompaniia "ProAhro" [Elektronnyi resurs]. Rezhym dostupu: www.proagro.com.ua.

6. Prosvitiv H. I. (2008). Marketynhovi doslidzhennia. Zavdannia y rishennia. M.: Alfa-Press.

7. Top 8 vyrobnykiv kombikormiv $\mathrm{v}$ Ukraini [Elektronnyi resurs]. Rezhym dostupu: http://latifundist.com/novosti/22186-top-8-proizvoditelej-kombikormov-v-ukraine

8. «Ukrainskyi klub ahrarnoho biznesu» [Elektronnyi resurs]. Rezhym dostupu: http://ucab.ua/ files/Survey/Doslidjenna/Manual_UCAB. pdf

9. Yaroslavskyi O. Ohliad sytuatsii na rynku kombikormiv v Ukraini. Proekt "Ahrarna polityka dlia liudskoho rozvytku" [Elektronnyi resurs]. Rezhym dostupu: http://www.undp.org.ua/agro/pub/ua/P2003_01_04 1_03.pdf.

10. FIVEX ANALYTICS GROUP [Elektronnyi resurs]. Rezhym dostupu: www.fivex.com.ua. 